\title{
Alishewanella jeotgali sp. nov., isolated from traditional fermented food, and emended description of the genus Alishewanella
}

\author{
Min-Soo Kim, ${ }^{1,2}$ Seong Woon Roh, ${ }^{1,2}$ Young-Do Nam, ${ }^{1,2}$ Ho-Won Chang, ${ }^{1}$ \\ Kyoung-Ho Kim, ${ }^{1}$ Mi-Ja Jung, ${ }^{1}$ Jung-Hye Choi, ${ }^{1}$ Eun-Jin Park ${ }^{1}$ \\ and Jin-Woo Bae ${ }^{1,2}$ \\ ${ }^{1}$ Department of Life and Nanopharmaceutical Sciences and Department of Biology, Kyung Hee \\ University, Seoul 130-701, Republic of Korea \\ ${ }^{2}$ University of Science and Technology, Biological Resources Center, Korea Research Institute of \\ Bioscience and Biotechnology, Daejeon 305-806, Republic of Korea
}

Correspondence Jin-Woo Bae baejw@khu.ac.kr
The genus Alishewanella is one of the major branches of the family Alteromonadaceae and was first proposed by Fonnesbech Vogel et al. (2000) to accommodate Alishewanella fetalis, isolated from an autopsy of a human fetus in 1992. Recently, another species, Alishewanella aestuarii, from a marine environment, has been reported (Roh et al., 2009). Here, we describe a third novel species that belongs to the genus Alishewanella, isolated from a traditional fermented food in Korea.

Strain $\mathrm{MS1}^{\mathrm{T}}$ was isolated from gajami sikhae (jeotgal), which is a traditional fermented food in Korea. A sample of gajami sikhae was diluted $10^{-6}$-fold with PBS and cultured on R2A agar (Difco). The 16S rRNA gene sequence was amplified by the colony PCR method with PCR Pre-Mix (Intron Biotechnology) and two universal primers for bacteria (Baker et al., 2003). The PCR products were sequenced with a BigDye Terminator Cycle Sequencing Ready Reaction kit (Applied

Abbreviation: TMAO, trimethylamine oxide.

The GenBank/EMBL/DDBJ accession number for the 16S rRNA gene sequence of strain $M S 1^{\top}$ is EU817498.
Biosystems) after purification according to the manufacturer's instructions. The reaction mixtures were analysed with an automated system (ABI Prism 3730XL DNA Analyzer; Applied Biosystems) and the 16S rRNA gene sequences were assembled with SEQMAN (DNASTAR). Comparison of the 16S rRNA gene sequence of strain $\mathrm{MS1}^{\mathrm{T}}$ with those deposited in GenBank revealed that strain $\mathrm{MS1}^{\mathrm{T}}$ belongs to the genus Alishewanella in the phylum Proteobacteria and that its $16 \mathrm{~S}$ rRNA gene sequence shares 98.67 and $98.04 \%$ similarity with the sequences of $A$. aestuarii $\mathrm{B}_{1} 1^{\mathrm{T}}$ and $A$. fetalis CCUG $30811^{\mathrm{T}}$, respectively. The $16 \mathrm{~S}$ rRNA gene sequence of the isolate was aligned with those of reference strains by using the multiple-sequence alignment program CLUSTAL $\mathrm{X}$ (1.83) (Thompson et al., 1997). The phylogenetic relationships between strain $\mathrm{MS1}^{\mathrm{T}}$ and the representative type strains of Alishewanella species were defined by MEGA4 (Tamura et al., 2007). In the randomly generated neighbour-joining, maximum-parsimony and maximumlikelihood consensus trees constructed from 1000, 1000 and 300 bootstrap replicates, respectively (Felsenstein, 1981; Kluge \& Farris, 1969; Saitou \& Nei, 1987), strain $\mathrm{MS}^{\mathrm{T}}$ formed a monophyletic clade that was separate 
from $A$. aestuarii $\mathrm{B} 11^{\mathrm{T}}$. The phylogenetic relationships between strain $\mathrm{MS1}^{\mathrm{T}}$ and its relatives are shown in Fig. 1.

In order to determine the extent of genetic relatedness, DNA-DNA hybridization experiments (Ezaki et al., 1989) were performed with modifications (Hirayama et al., 1996), with probe DNA labelled with photobiotin under a $400 \mathrm{~W}$ mercury-vapour lamp and boiling $\left(100{ }^{\circ} \mathrm{C}\right)$ for $30 \mathrm{~min}$. The genomic DNA reassociation values of strain $\mathrm{MS1}^{\mathrm{T}}$ with A. fetalis CCUG $30811^{\mathrm{T}}$ and A. aestuarii $\mathrm{B} 11^{\mathrm{T}}$ were 14.8 and $42.6 \%$, respectively. Bacterial strains with $16 \mathrm{~S}$ rRNA gene sequence similarities of $98 \%$ or lower are considered to be different species unless the extent of DNA-DNA relatedness is $>70 \%$ (Stackebrandt \& Goebel, 1994).

Media supporting the growth of strain $\mathrm{MS}^{\mathrm{T}}$ included tryptic soy agar, marine agar, nutrient agar, R2A agar, Luria agar (LA) (all from BBL/Difco) and $5 \%$ sheep blood agar. Optimal growth was seen with LA. To determine the optimal ranges of temperature, $\mathrm{NaCl}$ concentration and $\mathrm{pH}$ for growth, the strain was incubated on LA for $48 \mathrm{~h}$ at temperatures of $0,4,10,15,25,30,37,40$ and $45{ }^{\circ} \mathrm{C}$, with $\mathrm{NaCl}$ concentrations ranging from 0 to $14 \%(\mathrm{w} / \mathrm{v})$ and with $\mathrm{pH}$ ranging from 4.0 to 13.0 (with increments of $0.5 \mathrm{pH}$ units). Gram staining was performed according to the method described by Gram (1884). Cell shape, motility and size were determined by light microscopy (ECLIPSE $80 i$; Nikon) and transmission electron microscopy (JEM1010; JEOL). In addition, a flagellum-staining method (Heimbrook et al., 1989) clarified the presence of a single, polar flagellum. The motility of the isolate was observed directly by examination of the flagellum after growth on motility test medium (BBL) supplemented with $1 \%(\mathrm{w} / \mathrm{v})$ $\mathrm{NaCl}$. Catalase activity was examined by determining bubble production in $3 \%(\mathrm{v} / \mathrm{v})$ hydrogen peroxide solution. Oxidase activity was investigated by using $1 \%$ (w/v) p-tetramethyl phenylenediamine (bioMérieux). Enzyme activities, eight biochemical characters and utilization of sole carbon sources were determined with the API ZYM, API 20NE and API 50CH systems (bioMérieux), according to the manufacturer's instructions, with incubation at $30{ }^{\circ} \mathrm{C}$ for $24 \mathrm{~h}$ for the biochemical tests and for $72 \mathrm{~h}$ for the utilization tests. Reduction of trimethylamine oxide (TMAO), nitrite, ferric iron, thiosulfate and sulfite was defined by observing visible growth at $30{ }^{\circ} \mathrm{C}$ for 7 days under anaerobic conditions in modified LA medium $\left[1^{-1}: 5.0 \mathrm{~g}\right.$ yeast extract, $10.0 \mathrm{~g}$ tryptone, $20.0 \mathrm{~g}$ $\mathrm{NaCl}, 0.5 \mathrm{~g} \mathrm{MgCl}_{2} .6 \mathrm{H}_{2} \mathrm{O}, 0.2 \mathrm{~g} \mathrm{KH}_{2} \mathrm{PO}_{4}, 0.3 \mathrm{~g} \mathrm{NH} 4 \mathrm{Cl}$, $0.3 \mathrm{~g} \mathrm{KCl}, 0.015 \mathrm{~g} \mathrm{CaCl} 2.2 \mathrm{H}_{2} \mathrm{O}, 1 \mathrm{ml}$ trace element solution A (Loffler et al., 1996), 0.137 g sodium thioglycolate, $2.52 \mathrm{~g} \mathrm{NaHCO}$, $15.0 \mathrm{~g}$ agar, $1 \mathrm{ml}$ filter-sterilized vitamin solution (Wolin et al., 1963); final $\mathrm{pH}$ adjusted to $\mathrm{pH}$ 7.0-7.5, autoclaved and cooled to below $60^{\circ} \mathrm{C}$. The medium was poured and stored in an oxygen-free $\mathrm{N}_{2} / \mathrm{CO}_{2}$ $(80: 20)$ anaerobic chamber for at least 1 day. The final concentrations of various electron acceptors were $20 \mathrm{mM}$ each. The $\mathrm{G}+\mathrm{C}$ content was estimated by a fluorimetric method employing SYBR green and a real-time PCR thermocycler (Gonzalez \& Saiz-Jimenez, 2002). The method of phenol/chloroform extraction followed by ethanol precipitation was used to extract template chromosomal DNA (Sambrook et al., 1989). The genomic DNA of Escherichia coli KCTC $2441^{\mathrm{T}}$ was tested at the same time as the calibration reference. The cultural, physiological and biochemical characteristics of strain $\mathrm{MS}^{\mathrm{T}}$ are shown in Table 1 and Fig. 1.

To determine the cellular fatty acid composition of strain $\mathrm{MS1}^{\mathrm{T}}$, A. fetalis CCUG $30811^{\mathrm{T}}$ and A. aestuarii $\mathrm{B} 11^{\mathrm{T}}$, cultures were prepared on $5 \%$ sheep blood agar at $30{ }^{\circ} \mathrm{C}$ for $48 \mathrm{~h}$ before harvesting. The cellular fatty acids were extracted as described by MIDI (1999), analysed by gas chromatography (HP 6890; Hewlett Packard) and identified by using the Microbial Identification software package (Sasser, 1990). The cellular fatty acid profiles of the three isolates are presented in Table 2.

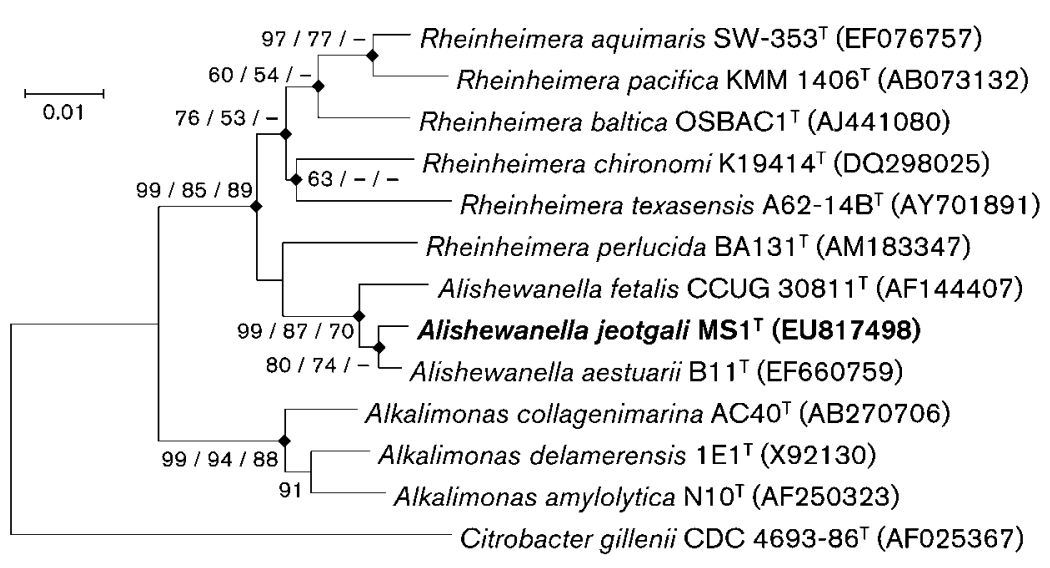

Fig. 1. Phylogenetic tree based on $16 \mathrm{~S}$ rRNA gene sequences, constructed with the neighbour-joining, maximum-parsimony and maximum-likelihood methods and based on the neighbour-joining consensus tree. Percentages at nodes $(>50 \%)$ are levels of bootstrap support based on the neighbour-joining/maximum-parsimony/maximum-likelihood methods as percentages of 1000/1000/300 replicates, respectively. Filled diamonds indicate generic branches that were present in phylogenetic trees generated by the neighbour-joining, maximum-parsimony and maximum-likelihood algorithms. Citrobacter gillenii CDC $4693-86^{\top}$ was used as the outgroup. Bar, 0.01 substitutions per nucleotide position. 
Table 1. Comparison of the characteristics of strain $M S 1^{\top}$ and its closest phylogenetic neighbours

Strains: 1, Alishewanella jeotgali sp. nov. $\mathrm{MS}^{\mathrm{T}}$; 2 , A. fetalis CCUG $30811^{\mathrm{T}}$ (data from Fonnesbech Vogel et al., 2000); 3, A. aestuarii $\mathrm{B} 11^{\mathrm{T}}$ (Roh et al., 2009). All of the biochemical data are from this study. All strains were positive for hydrolysis of gelatin, assimilation of maltose, sucrose and starch and reduction of TMAO, thiosulphate and nitrate. All strains were negative for production of indole, fermentation of Dglucose, hydrolysis of L-arginine, urea and $p$-nitrophenyl $\beta$-Dgalactopyranoside and reduction of sulfite, nitrite and ferric iron. + , Positive; -, negative; w, weak.

\begin{tabular}{|lccc|}
\hline Characteristic & $\mathbf{1}$ & $\mathbf{2}$ & $\mathbf{3}$ \\
\hline Isolation source & $\begin{array}{c}\text { Gajami sikhae } \\
\text { (jeotgal) }\end{array}$ & $\begin{array}{c}\text { Human } \\
\text { fetus }\end{array}$ & $\begin{array}{c}\text { Tidal flat } \\
\text { sediment }\end{array}$ \\
Motility & + & - & + \\
Growth at/in: & & & \\
$4{ }^{\circ} \mathrm{C}$ & $\mathrm{W}$ & - & - \\
$10{ }^{\circ} \mathrm{C}$ & + & - & - \\
$40{ }^{\circ} \mathrm{C}$ & - & + & + \\
$0 \% \mathrm{NaCl}$ & - & - & + \\
$6 \% \mathrm{NaCl}$ & - & + & - \\
$8 \%$ NaCl & - & + & - \\
Hydrolysis of aesculin & + & - & - \\
Assimilation of: & & & \\
Aesculin & + & - & - \\
D-Fructose & - & + & + \\
D-Glucose & + & - & - \\
Glycerol & - & + & - \\
Glycogen & + & - & - \\
Inositol & - & + & - \\
Malate & - & + & - \\
D-Mannitol & - & + & + \\
Raffinose & - & - & + \\
Trehalose & + & - & - \\
G+ C content (mol\%) & 53.6 & 51.0 & 49.5 \\
& & & \\
\hline
\end{tabular}

Phylogenetic analysis and the cultural, physiological and biochemical characteristics of strain $\mathrm{MS}^{\mathrm{T}}$ show that it is phylogenetically and phenotypically distinct from A. fetalis CCUG $30811^{\mathrm{T}}$ and $A$. aestuarii $\mathrm{B} 11^{\mathrm{T}}$. We propose that strain $\mathrm{MS}^{\mathrm{T}}$ represents a novel species that belongs to the genus Alishewanella, one of the major branches of the family Alteromonadaceae, and that this species should be named Alishewanella jeotgali sp. nov.

\section{Emended description of the genus Alishewanella}

The characteristics of the genus Alishewanella, described previously by Fonnesbech Vogel et al. (2000) and Roh et al. (2009), are as follows: Gram-negative, motile or nonmotile rods, oxidase- and catalase-positive, and the species vary in terms of the concentration of $\mathrm{NaCl}$ needed for growth. In addition, growth of species in the genus Alishewanella occurs at $4{ }^{\circ} \mathrm{C}$ or above. Utilization of glucose and reduction of nitrite are species-dependent.
Table 2. Comparison of the fatty acid contents of strain $\mathrm{MS}^{\top}$ and its closest phylogenetic neighbours

Strains: 1, Alishewanella jeotgali sp. nov. $\mathrm{MS}^{\mathrm{T}} ; 2$, A. aestuarii $\mathrm{B} 11^{\mathrm{T}}$; 3, A. fetalis CCUG $30811^{\mathrm{T}}$. All data were taken from this study. All strains were grown on $5 \%$ sheep blood agar at $30{ }^{\circ} \mathrm{C}$ for $48 \mathrm{~h}$. Values are percentages of the total fatty acids. $\operatorname{tr}$, Trace $(<1.0 \%)$; , not detected.

\begin{tabular}{|lccc|}
\hline Fatty acid (\%) & $\mathbf{1}$ & $\mathbf{2}$ & $\mathbf{3}$ \\
\hline $\mathrm{C}_{11: 0} 3-\mathrm{OH}$ & 2.3 & 2.3 & 1.7 \\
$\mathrm{C}_{12: 0}$ & - & $\operatorname{tr}$ & 1.0 \\
$\mathrm{C}_{12: 0} 3-\mathrm{OH}$ & 3.3 & 4.0 & 3.7 \\
$\mathrm{C}_{14: 0} 3-\mathrm{OH} / \mathrm{C}_{16: 1}$ iso I & 1.9 & 3.2 & 3.2 \\
$\mathrm{C}_{15: 0}$ & 1.4 & 1.2 & 1.9 \\
$\mathrm{C}_{15: 1} \omega 8 c$ & 1.6 & 1.1 & $\operatorname{tr}$ \\
$\mathrm{C}_{16: 0}$ & 13.4 & 11.4 & 14.3 \\
$\mathrm{C}_{16: 0}$ iso & 2.4 & 1.5 & $\operatorname{tr}$ \\
$\mathrm{C}_{17: 0}$ & 8.9 & 8.9 & 8.7 \\
$\mathrm{C}_{17: 1} \omega 6 c$ & 1.9 & 1.6 & $\operatorname{tr}$ \\
$\mathrm{C}_{17: 1} \omega 8 c$ & 19.8 & 18.4 & 16.0 \\
$\mathrm{C}_{18: 0}$ & - & 1.6 & 1.3 \\
$\mathrm{C}_{18: 0}$ iso & 2.0 & 1.8 & $\operatorname{tr}$ \\
$\mathrm{C}_{18: 1} \omega 7 c$ & 21.7 & 23.4 & 18.0 \\
$\mathrm{C}_{18: 1} \omega 9 c$ & 1.3 & 1.4 & 2.0 \\
$\mathrm{Summed} \mathrm{m}$ features & & & \\
1 & 1.8 & 2.4 & 1.9 \\
2 & 1.9 & 3.2 & 3.2 \\
3 & 16.5 & 13.4 & 15.0 \\
\hline
\end{tabular}

${ }^{*}$ Summed features are groups of two or three fatty acids that cannot be separated by GC with the MIDI system. Summed feature 1 contained $\mathrm{C}_{13: 0} 3-\mathrm{OH}$ and/or iso- $\mathrm{C}_{15: 1} \mathrm{H}$. Summed feature 2 contained $\mathrm{C}_{14: 0}$ 3-OH and/or $\mathrm{C}_{16: 1}$ iso I. Summed feature 3 contained $\mathrm{C}_{16: 1} \omega 7 c$ and/or iso- $\mathrm{C}_{15: 0} 2-\mathrm{OH}$.

\section{Description of Alishewanella jeotgali sp. nov.}

Alishewanella jeotgali (je.ot.ga'li. N.L. gen. n. jeotgali of jeotgal, a traditional Korean fermented seafood).

Motile, rod-shaped, Gram-negative, facultative anaerobe with a single, polar flagellum. Cells are $2-6 \mu \mathrm{m}$ long and about $1 \mu \mathrm{m}$ wide and are generally observed as single cells, although they can occur in pairs. Colonies are 3-4 $\mathrm{mm}$ in diameter, circular and raised, initially light ivory in colour and dark ivory later. Growth occurs at $4-40{ }^{\circ} \mathrm{C}$, in $1-2 \%$ $(\mathrm{w} / \mathrm{v}) \mathrm{NaCl}$ and at $\mathrm{pH}$ 6.5-9.5. Optimal growth occurs at $37{ }^{\circ} \mathrm{C}$, in $1 \%(\mathrm{w} / \mathrm{v}) \mathrm{NaCl}$ and at $\mathrm{pH}$ 6.5-9.0. Growth at $4{ }^{\circ} \mathrm{C}$ takes $>72 \mathrm{~h}$. Generally grows well for $>24 \mathrm{~h}$ on LA. MA, NA and TSA are also suitable for growth. Oxidaseand catalase-positive. Does not produce indole or Larginine dihydrolase. Positive for alkaline phosphatase, esterase $\left(\mathrm{C}_{4}\right)$, esterase lipase $\left(\mathrm{C}_{8}\right)$, leucine arylamidase, trypsin, $\alpha$-chymotrypsin, $\beta$-glucosidase, acid phosphatase and naphthol-AS-BI-phosphohydrolase, but negative for lipase $\left(\mathrm{C}_{4}\right)$, valine arylamidase, cystine arylamidase, $\alpha$ - and $\beta$-galactosidase, $\beta$-glucuronidase, $\alpha$-glucosidase, $N$-acetyl$\beta$-glucosaminidase, $\alpha$-mannosidase and $\alpha$-fucosidase (API 
ZYM). Positive for reduction of nitrate to nitrite, $\beta$ glucosidase (aesculin hydrolysis) and protease (gelatin hydrolysis), but negative for production of indole, fermentation of $\mathrm{D}$-glucose, $\mathrm{L}$-arginine dihydrolase, urease and $\beta$ galactosidase. Utilizes TMAO and thiosulfate as electron acceptors, but not nitrite, sulfite or ferric iron. Assimilates Dglucose and maltose, but not L-arabinose, D-mannose, Dmannitol, $N$-acetylglucosamine, potassium gluconate, capric acid, adipic acid, malate, trisodium citrate or phenylacetic acid (API 20NE). Assimilates aesculin, maltose, sucrose, trehalose, starch and glycogen, but not glycerol, erythritol, Dand L-arabinose, D-ribose, D- and L-xylose, D-adonitol, methyl $\beta$-D-xyloside, D-galactose, D-fructose, L-sorbose, Lrhamnose, dulcitol, inositol, D-sorbitol, methyl $\alpha$-D-mannoside, methyl $\alpha$-D-glucoside, $N$-acetylglucosamine, amygdalin, arbutin, salicin, cellobiose, lactose, melibiose, insulin, melezitose, raffinose, xylitol, gentiobiose, turanose, D-lyxose, D-tagatose, D- or L-fucose, D- or L-arabitol, gluconate or 2- or 5-ketogluconate (API 50CH). Major cellular fatty acids are $\mathrm{C}_{16: 0}, \mathrm{C}_{17: 0} \omega 8 c, \mathrm{C}_{18: 0} \omega 7 c$ and summed feature $3\left(\mathrm{C}_{16: 1} \omega 7 \mathrm{cl}\right.$ iso- $\left.\mathrm{C}_{15: 0} 2-\mathrm{OH}\right)$. The DNA G $+\mathrm{C}$ content of the type strain is $53.6 \mathrm{~mol} \%$.

The type strain, $\mathrm{MS}^{\mathrm{T}}\left(=\mathrm{KCTC} 22429^{\mathrm{T}}=\mathrm{JCM} 15561^{\mathrm{T}}\right)$, was isolated from gajami sikhae (jeotgal), a traditional Korean fermented seafood.

\section{Acknowledgements}

We thank Dr J. P. Euzéby (Ecole Nationale Vétérinaire, France) for etymological advice. This work was supported by NMC0300938, the Environmental Biotechnology National Core Research Center (KOSEF: R15-2003-012-02002-0) and TDPAF (Technology Development Program for Agriculture and Forestry).

\section{References}

Baker, G. C., Smith, J. J. \& Cowan, D. A. (2003). Review and reanalysis of domain-specific $16 \mathrm{~S}$ primers. J Microbiol Methods 55, 541555 .

Ezaki, T., Hashimoto, Y. \& Yabuuchi, E. (1989). Fluorometric deoxyribonucleic acid-deoxyribonucleic acid hybridization in microdilution wells as an alternative to membrane filter hybridization in which radioisotopes are used to determine genetic relatedness among bacterial strains. Int J Syst Bacteriol 39, 224-229.

Felsenstein, J. (1981). Evolutionary trees from DNA sequences: a maximum likelihood approach. J Mol Evol 17, 368-376.
Fonnesbech Vogel, B. F., Venkateswaran, K., Christensen, H., Falsen, E., Christiansen, G. \& Gram, L. (2000). Polyphasic taxonomic approach in the description of Alishewanella fetalis gen. nov., sp. nov., isolated from a human foetus. Int J Syst Evol Microbiol 50, 1133-1142.

Gonzalez, J. M. \& Saiz-Jimenez, C. (2002). A fluorimetric method for the estimation of $\mathrm{G}+\mathrm{C}$ mol\% content in microorganisms by thermal denaturation temperature. Environ Microbiol 4, 770-773.

Gram, H. (1884). Über die isolierte Färbung der Schizomyceten in Schnitt- und Trockenpräparaten. Fortschr Med 2, 185-189 (in German).

Heimbrook, M. E., Wang, W. L. \& Campbell, G. (1989). Staining bacterial flagella easily. J Clin Microbiol 27, 2612-2615.

Hirayama, H., Tamaoka, J. \& Horikoshi, K. (1996). Improved immobilization of DNA to microwell plates for DNA-DNA hybridization. Nucleic Acids Res 24, 4098-4099.

Kluge, A. G. \& Farris, F. S. (1969). Quantitative phyletics and the evolution of anurans. Syst Zool 18, 1-32.

Loffler, F. E., Sanford, R. A. \& Tiedje, J. M. (1996). Initial characterization of a reductive dehalogenase from desulfitobacterium chlororespirans Co23. Appl Environ Microbiol 62, 3809-3813.

MIDI (1999). Sherlock Microbial Identification System Operating Manual, version 3.0. Newark, DE: MIDI, Inc.

Roh, S. W., Nam, Y.-D., Chang, H.-W., Kim, K.-H., Kim, M.-S., Oh, H.-M. \& Bae, J.-W. (2009). Alishewanella aestuarii sp. nov., isolated from tidal flat sediment, and emended description of the genus Alishewanella. Int J Syst Evol Microbiol 59, 421-424.

Saitou, N. \& Nei, M. (1987). The neighbor-joining method: a new method for reconstructing phylogenetic trees. Mol Biol Evol 4, 406425.

Sambrook, J., Fritsch, E. F. \& Maniatis, T. (1989). Molecular Cloning: a Laboratory Manual, 2nd edn. Cold Spring Harbor, NY: Cold Spring Harbor Laboratory.

Sasser, M. (1990). Identification of bacteria by gas chromatography of cellular fatty acids, MIDI Technical Note 101. Newark, DE: MIDI Inc.

Stackebrandt, E. \& Goebel, B. M. (1994). Taxonomic note: a place for DNA-DNA reassociation and 16S rRNA sequence analysis in the present species definition in bacteriology. Int J Syst Bacteriol 44, 846849.

Tamura, K., Dudley, J., Nei, M. \& Kumar, S. (2007). MEGA4: molecular evolutionary genetics analysis (MEGA) software version 4.0. Mol Biol Evol 24, 1596-1599.

Thompson, J. D., Gibson, T. J., Plewniak, F., Jeanmougin, F. \& Higgins, D. G. (1997). The CLUSTAL_X windows interface: flexible strategies for multiple sequence alignment aided by quality analysis tools. Nucleic Acids Res 25, 4876-4882.

Wolin, E. A., Wolin, M. J. \& Wolfe, R. S. (1963). Formation of methane by bacterial extracts. J Biol Chem 238, 2882-2886. 